\title{
Techne as Technology and Techne as Art: Heidegger's Phenomenological Perspective
}

\author{
D. Rio Adiwijaya \\ DKV New Media, School of Design, BINUS University \\ Jln. KH. Syahdan No. 9, Jakarta 11480, Indonesia \\ (6221)5343830 ext. 2107 \\ rioadi@gmail.com \\ Yasser Rizky \\ DKV New Media, School of Design \\ BINUS University; Jl. KH. Syahdan No. 9, Jakarta 11480, Indonesia \\ (6221)5343830 ext. 2107 \\ yasser_rizky@yahoo.com
}

\begin{abstract}
We live in an age where our existence has been remarkably shaped by technology. However, as contemporary thinkers have elucidated, technology is not a mere sum of our tools. At a more profound level, technology forms an instrumental context that frames our relation to the world and to ourselves. Everything thereupon tends to appear merely as a means to an end. Countering the instrumentalistic tendencies of global technologization, this paper would like to ponder on the meaning of technology beyond mere tools. The core influence of this study is the thought of Martin Heidegger (18891976) which reveals that both technology and art stem from ancient techne, our basic way to reveal reality through embodied praxis. However, 2500 years of Western intellectual history has rendered the instrumental meaning of techne - that is, the way we understand technology today as practical utilization of science - becomes far more dominant than the artistic or poetic one. It is the aim of this literary study to elucidate Heidegger's dense phenomenological inquiry which reveals the dual meaning of techne: techne as technology and techne as art. Recovery of the forgotten poetic meaning of techne is crucial to counter instrumentalism that pervades art in our techno-scientific age.
\end{abstract}

Keywords: instrumentalism, embodied praxis, instrumental techne, poetictechne

\section{INTRODUCTION}

Nowadays, most of our lives take place in engineered environments, powered by electricity, equipped with lighting and water supply systems, air conditioners, audio-visual devices and so forth. As professionals from various fields including the art, our works rely on myriad of tools from computers and gadgets to art materials and instruments manufactured in large-scale industries. Indeed, for most of us as twenty-first century human beings, technology is like an oceanic habitat in which we make a living as if we were fish, rendering it inconspicuous to us due to its proximity, pervasiveness and ubiquity. 
In the modern art world, the invention of mechanical reproduction had ignited twentieth century visual art's inclination towards formal abstraction, setting aside its age-old preoccupation with mimesis. However, under the urge of constant renewal while the modern art itself was heavily saturated with form-driven specimens, one of the most possible breakthrough pointed out by Arthur Danto (as cited in Braembussche, 2009) was achieved through a staunch conceptual approach, initiated by artists such as Marcel Duchamp and Andy Warhol with their found objects art (pp. 153-155, 157). From then on, there emerged an approach that shattered the traditional distinction between art and non-art, since under a conceptual credo, everything can be made a work of art. Contemporary installations are still echoing what the 1960s conceptual artist Sol LeWitt said about the art of his cohort: "When an artist uses a conceptual form of art, it means that all of the planning and decisions are made beforehand and the execution is a perfunctory affair. The idea becomes a machine that makes the art" (LeWitt, 1999, p. 12).

However, when the the concept and not the physically created or performed works takes over the center stage, consequently artwork becomes 'dematerialized' (Lippard \& Chandler, 1999, pp. 46-50) and tends to appear as only a kind of message carrier or sign. Art's preoccupation with its own sign-like functionality was attested by modern day employment of semiotics in art (Bolt, 2004, pp. 116-117). Ironically, this 'immaterial' yet instrumentalistic conception of art also implies a 'self-cancellation' dilemma known as 'the end of art' put forward by figures such as Arthur Danto and Victor Burgin (Brand, 2000, p. 175). Judged only by its message-delivery function, art loses its inherent 'material' significance. Without purposely making the case worse, our technological predicament does not only affect our understanding of art, but of ourself. In today's language, we even conceive ourselves instrumentally, namely as 'human resources.'

The 'superstar' or 'celebrity' culture we often witness or experience in the art world, instead of a mark of individual liberation, is very likely a part and parcel of the ordering of those individuals within the production and consumption cycle of art as commodity. As cited in Bolt (2004), artists Josephine Starrs and Leon Cmielewski attested from their own experiences in the contemporary art scene that at first, celebrity artists themselves are regarded as products to be promoted in order to sell their artworks. Later when they have achieved enough fame and fortune, they can also be used as a tool to promote other products ( $\mathrm{p}$. 57). Of course, to be circulated within this commodification cycle is not the same as endorsing it. In other words, we may still engage in such a circumstance from a critical standpoint. What is crucial here is rather that technology, as a global phenomenon, does shape our mindset in a seamless but profound manner, at which point our common understanding of technology as just a tool is clearly inadequate, even exhibiting the problematic itself, that is, instrumentalism. 
Speaking of the instrumentalism that pervades us at societal level, it is necessary to take a glance over some major studies of techno-industrial society, such as those of Max Weber and Critical theorists (Horkheimer, Adorno, Marcuse, Habermas). Weber theorized that along with the modernization process in which techno-science played a constitutive role, there also came about the process of 'rationalization' which characterized society. Premodern people were deeply tied to and motivated by traditions, while rationalization led to societal structures and behaviours that were governed solely by goal-oriented or instrumental rationality (Gane, 2002, pp. 15, 24-27). Jürgen Habermas who shared Weber's concern asserted that the rationalization process had yielded 'colonization of lifeworld by system.' Our culturally rich and dialogical forms of life were more and more pervaded by instrumental logic of technocapitalistic system (Layder, 2006, pp. 224-226). As contemporary sociologist George Ritzer attested, we can still witness Weber's gloomy prognosis of modernity in an ever-increasing demand for calculability, predictability, control and efficiency over many aspects of our life today (Ritzer, 2010, pp. 16-17), e.g. through imposition of 'measurable performance' in education, 'certification' of profession, et cetera.

After seeing how profoundly technology has shaped us, we can now ask, how was that all possible in the first place? How could the human, the creator, become enslaved to his/her own creation, technology? Furthermore, is there still any significant place for art in the age where technology has become so dominant, and where its instrumental or goal-directed thinking seems to be the only logical way to think? Is there any meaning of art more than a message-delivery tool? It is no coincidence that Martin Heidegger (1889-1976), one of the most influential thinker of the twentieth century, occupied his life and work with fundamental questions such as the ones above. He does have some very fresh and original, yet deep and illuminating answers about the human condition, and its co-constitutive relationships with technology, and with art.

To appropriate Heidegger's enlightening answers, it is first required to grasp the basics of his pivotal approach, namely phenomenology. Accordingly, the first discussion in this paper is of Heidegger's phenomenology, which revealed our basic constitution as being-in-the-world instead of subject vis-à-vis object. As being-in-the-world, we firstly engage reality immediately vested with our practical interest in a 'mindless skillful' manner (Dreyfus, 1991, p. 3), before we access them as objects of disinterested cognition. In other words, our most basic way to relate to reality occurs through embodied praxis or techne, not theoria or cogito as traditional and modern philosophy think. This topic will occupy the second part of this paper. However, techne, as Heidegger suggested, does not merely bring forth instrumental things (i.e. tools or technology) but also noninstrumental yet meaning-bestowing artworks, as will be discussed in the third and final part. Here we discover the phenomenological significance of techne as art, that is, the disclosure of reality in a qualitatively meaningful way, in contrast to techne as technology that reveals reality solely as quantifiable function. 


\section{HEIDEGGER: THE QUEST FOR THE MEANING OF BEING THROUGH PHENOMENOLOGY}

Heidegger is well known for his life long quest for the meaning of being. Being, a traditional subject for ontology or metaphysics, is perhaps too abstract for us who are concerned about art and technology. However, what he means by being is neither an abstract entity that exists beyond perceptible reality, nor a special concrete entity among others, nor the sum of all entities, nor an aspect of entities (Carman, 2013, pp. 84-85). So, what is being and why it is important? Firstly, we should notice that Heidegger did not ask about 'being' per se but about 'the meaning of being.' As Carman noted, his question is actually "what does it mean to be" anything at all (p.85), as we often ask in sentences like "what does it mean to be a cat?" or "what does it mean to be a human being?" and so forth. This question, as simple or as superficial as it may seem, is actually a very fundamental yet very difficult to answer. Indeed, since Being and Time (1962), Heidegger decided to embark on his quest for the meaning of being (of many entities, i.e., human, natural, technological, or artistic entities) by firstly interrogating the only entitiy that concerns about the meaning of its own being, that is, us, the human being (pp. 32-35).

To be sure, Heidegger did not begin from square one since philosophical tradition has already provided some answers, but these he deemed to be a misinterpretation of the meaning of being. For Heidegger, the whole Western philosophical tradition has misinterpreted the meaning of being of either human or non-human entities as substance, i.e., the underlying 'what-ness' or essence of all entities that remains unchanged over time (Frede, 1993, pp. 43-46, 61). For Plato of the antiquity, what underlies all entities is their eidos or form, i.e., their perfect and permanent 'blueprint' which can only be accessed through theoretical inquiries. For the medievals, the underlying essence shared by all entities is ens creatum (created beings). It is under the influence of the progenitor of modern thinking, René Descartes, that we have been inclined to think that there are basically two kinds of substance: the mental that thinks and the material that occupies space (Guignon, 2005, p. 92). Today, it is still very common to assume ourselves to be a combination of non-physical mind and physical body, to see an artwork as a mixture of mental concept and physical medium, or a natural object as an entirely physical entity.

As a field of philosophical research, Heidegger did not find anything inherently wrong with metaphysics. However due to its historical sedimentation in language, substance metaphysics eventually becomes worldview, and in our time, it has been so tyrannical in framing our mindset that it "drives out every other possibility of revealing" (Heidegger, 1977, p. 27). One of the most harmful effects of Cartesianism is the reduction of the meaning of reality to mere objects to be dominated by man, the thinking subject. Beginning from the interpretation of her/himself as an entity that has a mental-thing 'inside,' entirely separated from material reality 'outside,' Descartes also initiated representationalism, that is, a belief that our most basic yet ultimate access to reality occurs through 
mental representation or ideas inside our mind. This common metaphysical assumption has many peculiar consequences, for example, excessive theoreticism which presumes that all human ability consists of having a theory that can be transparently formalized (Clark, 2002, pp. 9-17, Dreyfus, 1991, pp. 1-6). Next, a sharp division between what is considered to be merely inside and what is truly outside, which in turn deems qualitative meaning as merely 'subjective' and quantitative empirical facts as 'objective' (Guignon, 2005, p. 92). Modern trivialization of art as merely subjective fiction vis-à-vis scientific knowledge as the one and only objective truth surely has Cartesianism as its culprit.

Finally, the Cartesian binary and its representationalism culminates in the age of technology when its bureaucratically controlled forms of life is embraced all over the modernized globe. Within this technologically 'enframed' world, human and non-human entities are even no longer appear as distinct subject and object but rather equally as 'resources' to be maximally utilized (Heidegger, 1977, p. 18). As Iain Thomson (2011) explained, subject-object dualism precisely becomes technological enframing "when the subject objectifies itself - that is, when the human subject, seeking to master and control all aspects of its objective reality turns that modern impulse... back on itself" (p.58). Representational thinking, though initially was one of the most important self-discoveries which empowered human beings, has now led modern humanity to systematic domination of all entities including him/herself. To release ourselves from the grip of Cartesianism, Heidegger's strategy in Being and Time was to show that the subject-object binary itself is a metaphysical construct that does not determine our basic 'way to be' in concrete life.

To let our way to be in concrete life show itself, Heidegger is indebted to Edmund Husserl's phenomenology. Prior to Heidegger, phenomenology for Husserl was a rigorous self-examinaton of the inquirer's own consciousness, with a goal of providing a firm epistemological basis for science, since all scientific knowledge is constituted in consciousness. Husserl's aim was to achieve a comprehensive account of how knowledge is given to consciousness (Zahavi, 2003, p. 12).

Husserl's crucial finding is the intentional character of consciousness, which means, consciousness never occurs vacuously as if it is an empty container but always intending something, or directed towards an object outside of itself. We can see that intentionality already exceeds Cartesian sharp-dualism, since subject and object for Husserl are inter-dependent or presuppose one another (Moran, 2005, p. 50). Indeed, Husserl rehabilitates the role of the human subject in constituting knowledge, including the objective-scientific one.

Heidegger embraced Husserl's intentionality, but at the same time saw that the latter was still trapped within Cartesian metaphysics by accepting pure consciousness of subject as a zero-point of intentionality. For Heidegger, there is no pure point to which we can anchor ourselves to get a neutral view of things. It is true that we could only begin from the first-person perspective or the 'I,' but for Heidegger, there is no evidence that there is any metaphysical substance, i.e., 
subject or 'mental-thing' that underlies the ' $\mathrm{I}$ ' in accessing reality. It is actually my prior involvement in practical affairs of my social milieu that gave me first access to things, other people, and myself (Guignon, 1993, p. 6). Heidegger named this co-constituve intentional relation between us and our socio-practical context: being-in-the-world, a relation that occurs at a pre-reflective level of engagement prior to conscious intending.

\section{BEING-IN-THE-WORLD AND TECHNE}

To say that we exist as being-in-the-world does not mean that we merely occupy a spatial coordinate of planet earth which can be located by a GPS. Prior to the geometrization of space-time, the world we are being-in is a space of familiarity that envelopes our relations to things, people and ourselves in a pre-relective manner. It could be a world of family, a world of office workers, a world of academia, a world of art, and so forth. Each world serves as a backgound whole in which things and people including ourselves directly show up in the foreground as its meaningful parts. In our daily academic world for example, we find ourselves already coping with things (e.g., computer, printer and paper) in-order-to produce scholarly writings whereof words can be composed on papers towards sending it to a seminar, for-the-sake-of our own self-realization as academics. Things barely appear as meaningless and unrelated to each other and to us but always already within the world's referential structure: ... in-order-to ... whereof ... toward-which ... for-the-sake-of-which ... (Heidegger, 1962, pp. 91-122).

In contrast to this basic human way of being as being-in-the-world, the Cartesian subject merely occupies a uniform geometric space where she/he firstly encounters things as meaningless objects for her/his bare perception. Things become meaningful only through subjective value-predication or arbitrary conceptual imposition inside the mind, explaining why Cartesianism may lead us to crisis of meaning. Replacing the concept of subject, Heidegger's German neologism for the human entity whose basic way to be is being-in-the-world is Dasein. Translated literally, Dasein means being-there, which is actually Heidegger's designation for an a-priori human 'openness' towards worldly contexts instead of being enclosed within itself as an ego (Dreyfus, 1991, p. 13). As discussed earlier, Cartesian ego is actually a metaphysical (i.e. hypothetical) substance which is conceived to be entirely self-sufficient and isolated from any worldly context. While as Dasein, we and the world basically constitute each other from the very start in a part-whole relationship.

Self and world belong together in a single entity, the Dasein. Self and world are not two beings, like subject and object, or like I and thou, but self and world are the basic determination of the Dasein itself in the unity of the structure of beingin-the-world. (Heidegger, 1988, p. 297)

One can indeed question the a-priori validity of being-in-the-world in disclosing entities as already familiar to us, for does one not become familiar with things by recognizing them in cognition one after another? But if we begin our existence 
from the position of a worldless subject who basically accesses things through bare cognition, then we should begin by merely perceiving things as meaningless objects. Computers, printers, stack of papers, et cetera in our office should firstly be perceived as mere box-shaped objects of assorted sizes, colors and textures without any significance, then we must attach meaning to each of them in a piecemeal manner, followed by relating each thing to the others until it forms a coherent whole, then we know what to do amids them. In fact, our daily encounters with things never proceed in a such a way. We 'proximally and for the most part' find ourselves already coping with things we are already familiar to, in order to pursue the socio-practical goals we are already aiming towards.

For us whose constitution is being-in-the-world, things within the world are thereby initially revealed as "ready-to-hand" or equipmental things through daily coping, prior to their disclosure as "present-at-hand" or neutral objects for bare perception as Descartes suggested (Heidegger, 1962, pp. 97-98). This praxical yet embodied disclosure of reality as equipmental things does not apply only to man-made artifacts but to nature. "The wood is a forest of timber, the mountain a quarry of rock; the river is water-power, the wind is wind 'in the sail'"' (p. 100). It is only in total absence of Dasein (which is impossible since we in fact, are) or when our initial coping runs into breakdown that equipmental things begin to occur as neutral objects for disengaged cognitive perception. For Heidegger, this equipmental breakdown is the origin of theoretical attitude, which implies that human praxis never emerges from some previously established theories. It was philosophy since Plato that has misinterpreted humanity's prime comportment towards reality as cognitive or theoretical in nature. However, Heidegger discovered that the Pre-Socratic before Plato has recognized this praxical yet axiomatic way to reveal the real in their concept: techne, the etymological source of today's term technology. In the introduction to Heidegger's The Question Concerning Technology (1977), Leavitt explained this broad sense of techne.

Techne was a skilled and thorough knowing that disclosed, that was, as such, a mode of bringing forth into presencing, a mode of revealing. (p. xxv)

Here, Heidegger has no other intention than implying that humanity and technology co-constitute each other from the very beginning, which means they both are each other's perpetual condition for being what they are. This coevolution between human and technology also means that we can never escape technology, since our very being is already technological from the start. Stated differently, technology is never merely the total sum of artifacts 'out there,' but rather, the artifact itself is already an outcome of our 'technological' way of comporting ourself embodiedly towards the world (i.e. techne). Even theoria which became axiomatic for Western humanity since Plato and Aristotle is regarded by Heidegger as emerging from both thinkers' unrealized projection of technological attitude towards the cosmos as whole. Zimmerman (1990) glosses this technologically-contaminated inquiry of Plato and Aristotle into the nature of reality as "productionist metaphysics." 
The metaphysical schemes of Plato and Aristotle, Heidegger argued, were based on the view that the structure of all things is akin to the structure of products or artifacts. Aristotle's metaphysics, for example, is 'productionist' insofar as he conceived of all things, including animals, as 'formed matter'. The most obvious example of such 'formed matter' is the work produced by an artisan who gives form to material. Plato and Aristotle seemingly projected onto all entities the structure of artifacts. (p. 157)

This short glimpse into Heidegger's deep vision about technology more or less illustrates why Western culture for him inevitably culminates in the technological era, that in turn it becomes a threat to humanity through its pervasive instrumental mindset.

However, if technology itself is nothing but the basic co-constitution of our own being, then the big question is how can we ever release ourself from the grip of instrumentalism that Heidegger himself despises? It turns out that Heidegger (1977) also indicated that in ancient times, techne did not only disclose reality instrumentally, but also poetically (i.e., as artworks).

Once that revealing that brings forth truth into the splendor of radiant appearing also was called techne. Once there was a time when the bringingforth of the true into the beautiful was called techne. And the poiesis of the fine arts also was called techne. In Greece, at the outset of the destining of the West, the arts soared to the supreme height of the revealing granted them. They brought the presence [Gegenwart] of the gods, brought the dialogue of divine and human destinings, to radiance. And art was simply called techne. (p.34)

Simply stated, the only way to counter-balance the instrumental side of techne for Heidegger is through techne itself, though its non-instrumental side, that is, art.

\section{TECHNE AS TECHNOLOGY AND TECHNE AS ART}

To be able to experience art as a counter balance to technological frenzy, we should pay attention to how Heidegger differentiate the phenomenality of equipments and artworks. As mentioned earlier, equipmentality of things is disclosed at the same time we engage them through daily coping. However, equipmental things have a very peculiar phenomenality: they are disclosed in a transparent manner. This transparency becomes obvious if we take examples of our 'nearest' equipments such as clothes, shoes, or glasses. When we use these proximal items, we don't pay attention to them but instead to the goal of our practice. We are busy reading books by wearing glasses, while the glasses themselves becomes barely noticable. This transparency is also tied to the fact that any equipment is disclosed within the referential structure of the world as previously discussed. A hammer, for example, never exists individually but always in its reference to nails, then nails refer to woodboards, woodboards to furniture, furniture to houses, houses to districts, districts to cities, et cetera, until it forms our world as an 'equipmental totality,' which is also transparent to us insofar as we immerse ourselves in it in daily life. A city as an equipmental whole remains inconspicuous until a breakdown such as electricity failure occurs, 
modifying its previous transparency into an explicit availability (i.e. natural object) for our rational scrutiny.

In the early parts of The Origin of the Work of Art (1975), Heidegger begins to describe initial differences between equipmental things and artworks, that the latter do not need equipmental breakdown to explicitly announce themselves. It could be related to art's 'thingly character,' eg. "colored in painting" or "sonorous in musical composition" as Heidegger begins to ponder (p. 19). However, this attempt to capture the phenomenality of artwork from its mere materiality ended in the need to add immaterial values or concepts to that material thing for it to be valued as art. This is precisely the way binary substance metaphysics frames our basic understanding of everything, the way that Heidegger expects to overcome. Returning to his phenomenological position that things are initially revealed as equipmental things and not mere things, Heidegger in The Origin decides to directly compare phenomenal differences between an equipmental thing and a painting of equipment, in his case a pair of farmer's shoes and Van Gogh's painting of shoes. The comparison itself is carried out in a very unorthodox manner, in which Heidegger attempts to redescribe real farmer's shoes (which are of course unavailable for Heidegger at the time he visits the gallery where Van Gogh's painting is displayed), with the help of the painting (p. 33). This sequential and careful reading of The Origin of the Work of Art is necessary to avoid the false impression that Heidegger is attempting to interpret the content of Van Gogh's painting.

Before attending to the painting, Heidegger already brings an example, that is, the real shoes of a female farmer, probably from rural Southwest Germany, the same area where Heidegger lived. Heidegger begins by describing the transparent phenomenality of real shoes from within the world of the farmer herself.

The peasant woman wears her shoes in the field. Only here are they what they are. They are all the more genuinely so, the less the peasant woman thinks about the shoes while she is at work, or looks at them at all, or is even aware of them. She stands and walks in them. That is how shoes actually serve (p. 33).

The only way for the shoe to be individuated from its world as equipmental totality in Being and Time is through equipmental breakdown, which then modifies the transparent phenomenality of equipment into an explicit object. Now as Heidgger moves his attention away from real shoes of the farmer to the painting of Van Gogh, suddenly he sees:

From the dark opening of the worn insides of the shoes the toilsome tread of the worker stares forth. In the stiffly rugged heaviness of the shoes there is the accumulated tenacity of her slow trudge through the far-spreading and ever-uniform furrows of the field swept by a raw wind. On the leather lie the dampness and richness of the soil. Under the soles slides the loneliness of the field-path as evening falls. In the shoes vibrates the silent call of the earth, its quiet gift of the ripening grain and its unexplained self-refusal in the fallow desolation of the wintry field. This equipment is pervaded by uncomplaining anxiety as to the certainty of bread, the wordless joy of having once more 
withstood want, the trembling before the impending childbed and shivering at the surrounding menace of death (pp. 33-34).

Clearly Heidegger is not interpreting the content of Van Gogh's painting, but rather speaking about the shoes of the German farmer in the way he describes equipmental things in Being and Time. But this time he does not describe it directly but through the facilitation of Van Gogh's painting. Heidegger indeed sees the difference between seeing the shoes directly and indirectly (through painting). Directly seen, real shoes appear as something ready to wear. If we notice some worn marks on the leather, it is only a sign for us to check whether the shoes need a maintenance or a repair. In short, it is all about the functionality of the shoes. But seen through the painting, it now appears that those worn shoes do not only belong to an equipmental context, but to 'earth,' the source of its poetic meaning beyond mere funtionality (Kockelmans, 1986, 131-132). From this illuminative power of painting then Heidegger concludes that a simple mimetic painting of Van Gogh's pair of shoes neither merely represents a real object, nor merely expresses its painter's intention, but reveal 'the truth' of reality (Heidegger, 1975, p. 35), that is, the inherent and qualititative meaning of things, in this case, a pair of shoes.

The ordinary significance of equipment is usually its 'usefulness' (p. 34) or functionality. Here, we should remember that for Heidegger's phenomenology, every equipmental thing always refers to another equipmental thing, e.g., hammer refers to nails, nails to woodboards, woodboards to furniture and so on until they form an equipmental totality. Every equipmental thing therefore does not have any intrinsic significance, since it is determined by its function to fulfill certain extrinsic goals, which in turn refer to other extrinsic goals, and so on ad infinitum. In modern age, the functionality of equipment is determined quantitatively, e.g., by measuring its efficiency in fulfilling its function. Less efficient equipment is usually deemed to be obsolete and disposable. However, the worn marks on the shoes in Van Gogh's painting which have nothing to do with functional decay, reveal an even more original yet qualitative meaning of equipment, that is, its 'reliability' (pp. 34-35). When we wear out our equipment, this 'reliability' is indeed inconspicuous. Only through the illumination of the painting, it is revealed that the worn marks are a sign that the shoes have always been relied upon, in Heidegger's case, by the farmers in roaming the earth. Earth is nature's materiality that sustains the world, but remain excessive or lies outside its horizon of practical inteligibility (Polt, 2011, p.38, Mitchell, 2010, p.10). Earth as 'excess' that is resistant to the world's daily instrumental logic can be seen in Heidegger's lyrical description about nature that gives harvest (instrumentality) but also scarcity (resistance). While there should be earthy elements in every equipment, earth only appears conscpicuously through artworks due to its non-instrumental or poetic treatment of materiality. "The work lets the earth be earth" (p. 46). 
In The Origin, Heidegger further discusses the difference between the instrumental and poetic treatment of materiality, or between instrumental and poetic techne. In the citation below, Heidegger refers to his second example of artwork, that is, a Greek temple that due to its monumental nature is more capable of demonstrating an artwork's capacity for opening up a cultural world.

In fabricating equipment - e.g., an ax - stone is used, and used up. It disappears into usefulness. The material is all the better and more suitable the less it resists perishing in the equipmental being of the equipment. By contrast the temple-work, in setting up world, does not cause the material to disappear, but rather causes it to come forth for the very first time and to come into the open of the works's world. The rock comes to bear and rest and so first becomes rock; tones to sing, colors to glow, tones to sing, the words to speak (p. 46)

For Heidegger, artworks as intentional things, that is, things that have a coconstitutive relation with us, originally emerged through our own poetic treatment of materiality. But in our techno-scientific age, art tends to become more and more dematerialized and overly conceptualized. Heidegger's ouevre could remind us that poetic embodied praxis which does not merely treat things abstractedly and instrumentally is in fact the condition of possibility of the emergence of something that we can call art at all. As something that is noninstrumental in nature, an artwork is indeed something that can still meaningfully speak to us about the intrinsic and qualitative significance of many things. Even our 'tragic' mortality can be brought forth in a beautiful way, only through the poetic nature of art. Speaking of mortality, the technological mindset is of course incapable of conceiving it as more than a 'functional failure.'

\section{REFERENCES}

Bolt, Barbara. 2004. Art Beyond Representation: The Performative Power of the Image. London: I.B. Tauris \& Co Ltd.

Brand, Peg. 2000. "Glaring Omissions in Traditional Theories of Art." In Theories of Art Today. (N. Carrol, Ed.). Madison: The University of Wisconsin Press. Pp. 175198.

Carman, Taylor. 2013. “The Question of Being". In The Cambridge Companion to Heidegger's Being and Time. (M. Wrathall, Ed.). Cambridge: Cambridge University Press.

Clark, Timothy. 2002. Martin Heidegger. London: Routledge.

Dreyfus, Hubert. 1991. Being-in-the-World A Commentary on Heidegger's Being and Time, Division I. Massachusets: The MIT Press.

Frede, Dorothea. “The Question of Being: Heidegger's Project." In The Cambridge Companion to Heidegger. (C. Guignon, Ed.). Cambridge: Cambridge University Press. Pp. 42-69.

Gane, Nicholas. 2002. Max Weber and Postmodern Theory: Rationalization versus Reenchantment. Hampshire: Palgrave.

Guignon, Charles. 1993. “Introduction." In The Cambridge Companion to Heidegger. (C. Guignon, Ed.). Cambridge: Cambridge University Press. Pp. 1-41. 
Guignon, Charles. 2005. "Heidegger's Anti Dualism: Beyond Mind and Matter". In Heidegger's Being and Time, Critical Essays. (R. Polt, Ed.). Maryland: Rowman \& Littlefield Publishers Inc.,

Heidegger, Martin. 1962. Being and Time (J. Macquarrie, \& E. Robinson, Trans.). New York: Harper \& Row, Publishers, Inc. Harper Colophon Books. 1975. Poetry, Language, Thought (A. Hofstadter, Trans.). New York: . 1977. The Question Concerning Technology and Other Essays (W. Lovitt, Trans.). New York: Harper \& Row, Publishers, Inc. . 1988. The Basic Problems of Phenomenology (A. Hofstadter, Trans.). Bloomington: Indiana University Press.

Kockelmans, Joseph. 1986. Heidegger on Art and Art Works. Dordrecht: Martinus Nijhoff Publishers.

Layder, Derek. 2006. Understanding Social Theory. London: Sage Publications.

LeWitt, Sol. 1999. "Paragraphs on Conceptual Art." In Conceptual Art: A Critical Anthology. (A. Alberro \& B. Stimson, Eds.). Massachusets: The MIT Press. Pp. 1217.

Lippard, Lucy \& Chandler, John. 1999. "The Dematerialization of Art" in Conceptual Art: A Critical Anthology. (A. Alberro \& B. Stimson, Eds.). Massachusets: The MIT Press. Pp. 46-50.

Mitchell, Andrew. 2010. Heidegger Among the Sculptors, Body, Space, and the Art of Dwelling. Stanford: Stanford University Press.

Moran, Dermot. 2005. Edmund Husserl, Founder of Phenomenology. Cambridge: Polity Press.

Ritzer, George. 2010. McDonaldization: The Reader. London: Sage Publications.

Thomson, Iain. 2011. Heidegger, Art, and Postmodernity. Cambridge: Cambridge University Press.

Van den Braembussche, Antoon. 2009. Thinking Art. (M. Krassilovsky, R. H .C de Groot, \& D. van Spronsen, Trans.). Brussels: Springer.

Zahavi, Dan. 2003. Husserl's Phenomenology. Stanford: Stanford University Press.

Zimmerman, Michael. 1990. Heidegger's Confrontation with Modernity: Technology, Politics, and Art. Bloomington: Indiana University Press. 